\title{
A Label for Opening of the Mouth Implements from the Burial of Senneferi (TT99) and Remarks on the Ritual
}

\author{
Briant Bohleke, Nigel Strudwick
}

\begin{abstract}
In 2009, Nigel Strudwick published a paper drawing attention to a number of objects found in TT99 which seem to have been used in the Opening of the Mouth ritual. In 2015 an hieratic label from the same burial was identified as possibly belonging to a bag or box in which these items were kept. This paper presents a full edition of the label, and offers further comments on the context where the objects were found, and also indicates lines of research for further study of the Opening of the Mouth ritual.
\end{abstract}

Keywords: Senneferi, TT99, Thebes, tomb, Opening of the Mouth, hieratic label, ritual, Eighteenth Dynasty Egypt

Briant Bohleke, Lutheran Theological Seminary in Gettysburg, Gettysburg; bbohleke@ltsg.edu

Nigel Strudwick, University of Cambridge, Cambridge; ncs3@cam.ac.uk

In 2009, Nigel Strudwick published a paper in the Festschrift for Irmtraut Munro ${ }^{1}$ in which he identified a number of unusual finds as elements of a set of implements for the performance of the Opening of the Mouth ritual which was placed in the burial chamber of the tomb of Senneferi at Thebes (TT99). ${ }^{2}$ Such objects have never been previously identified at Thebes, the only parallels coming from the Late period tomb of Tjanenhebu at Saqqara. Further possible objects have been identified in post-excavation research since 2009, the most important of which is the label forming the subject of the present paper. ${ }^{3}$

\footnotetext{
${ }^{1}$ Strudwick 2009.

${ }^{2}$ The New Kingdom elements of the tomb of Senneferi are now published as Strudwick (Ed.) 2016. The web site Fitz Museum can be consulted for further information.

${ }^{3}$ Bohleke is responsible for the first section ('The hieratic label') of this paper; Strudwick, as the excavator, recognised the connection with the other Opening of the Mouth items found in TT99. He is responsible for all of the remaining sections, with the exception of that entitled 'To what was the label attached?', contributed by Bohleke. Both authors take overall responsibility for the whole paper.
} 

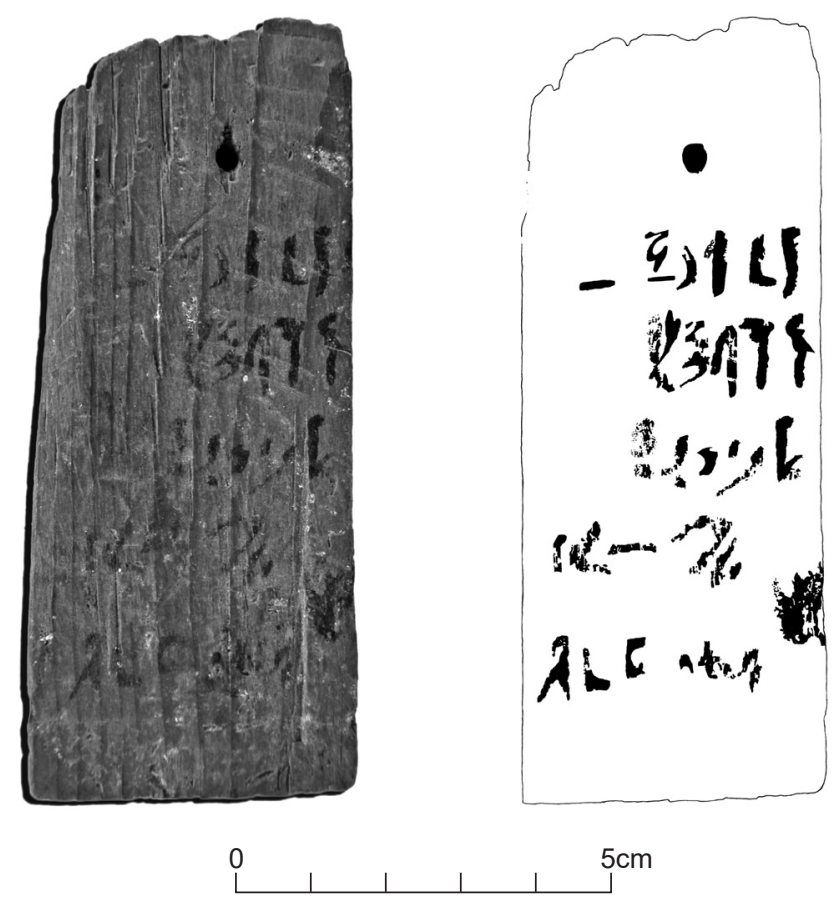

1. Photo and facsimile of the hieratic label, exc. no. 99.98 .0622 (Phot. A. Middleton (C N. Strudwick; facsimile by B. Bohleke).

\section{THE HIERATIC LABEL (EXC. NO. 99.98.0622) (Fig. 1)}

\section{DESCRIPTION}

A wooden object measuring approximately $3.6 \mathrm{~cm}$ wide (maximum) by $9.0 \mathrm{~cm}$ high, with a thickness of $0.4 \mathrm{~cm}$, was found among disturbed and fragmented burial goods in Shaft I Room 3 of TT99. The top is intentionally rounded, and this arc is preserved through deterioration of the edge that conforms to the approximate original curve. A $2 \mathrm{~mm}$ diameter hole has been drilled $1 \mathrm{~cm}$ from the top and seemingly to the right of the current centre, either to avoid the vertical raised ridge present there or because it had been centred. The right edge of the label has split off at some time after the hole's creation, but if a sliver of wood has actually been lost at the right, little to no inked text accompanied the slim section. It appears, indeed, that all the lines begin well in from the right side of the label.

The inscribed surface was prepared with an adze, planing from the top left downward along the grain. As the artisan moved the instrument to the right, the adze overlapped its preceding column, diminishing the width of each of the previous columns. The second to the last column remains the widest, clearly retaining the horizontal gouges of the blade as it met opposition and the craftsman had to provide another staccato stroke to continue his work. The final column has dug deepest into the wood, and the tilted blade of the adze 
may have been the cause of the theoretical right edge splitting off prior to the application of any ink.

Horizontal gouges and vertical ridges and valleys provided an uneven surface for the scribe to add five short and hasty lines of text in black ink. The palaeography conforms to that of the reign of Thutmose III. The strokes are thick and dark, yet the ink of some hieratic signs has flaked or has been abraded. The verso of the tag remained blank and the surface of each side received no other treatment.

No contemporary labels seem to exist; other Eighteenth Dynasty parallels in purpose and chronology derive from the tomb of Amenhotep III $^{4}$ and the tomb of Tutankhamun, of which the latter are the more important. Černý did not identify the species of tree from which Tutankhamun's labels originated, choosing instead the generic term 'wood' for each. It is most plausible that the material for Senneferi's and Tutankhamun's labels come from acacia or sycomore fig trees, both of which were common in Egypt and produce low grade wood. The preparation of Tutankhamun's labels has their surface appearing very similar to that of the label currently under study. ${ }^{5}$

\section{HIEROGLYPHIC TRANSCRIPTION}

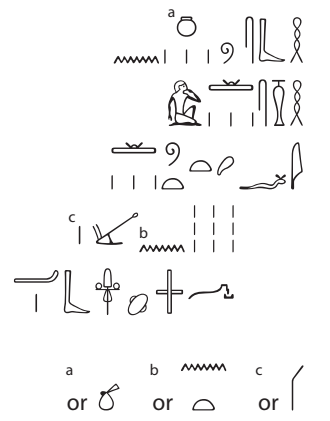

TRANSLITERATION

hbs.w $n$

$h s . w$

$i(w) f t w t$

pse $n$ hbny

$n w$ imy-wt $3 b w$

TRANSLATION

Implements for

the funerary ritual

(and) meat - assembled together.

Nine (items) of ebony (and)

the adze (named) Imy-wt, (of) ivory.

\footnotetext{
${ }^{4}$ These came to our attention very late, see: Yoshimura 2011: Figs 42-43 (236-238). These three labels mention 'best $b 3 k t$ oil', perhaps moringa, although the definitive assignment of the species to this oil has yet to be proved (Serpico, White 2000: 394-396).

${ }^{5}$ Černý 1965: 15-16, 27-28, Pls IX-X (nos 61-75).
} 


\section{COMMENTARY}

\section{LINE 1}

There appears to be a blob of ink at the current right edge of the text, but this is most likely a small crevice in the wood which is dark to the observer because of the shadow its pit creates. It is doubtful that any signs preceded those that are now present, and in ensuing lines there are no partial signs that would parallel the position of the one here.

The $\&$ is dissimilar to the more ornate equivalent sign directly below it. The top bulge may have been thwarted by the boundary made by the raised ridge to the immediate left of the sign. The $-\infty-$ sign has also been confined by its parallel raised ridge, though some faint ink marking the shorter fold of the sign is barely visible to the left of the ridge, securing the reading. The writing of the large 9 curve for the 11 sign is unparalleled in the remainder of the text, the scribe using the more usual cursory elongated-s instead for the $w$-coil.

The first word is determined by $\delta$ or $\theta$, either option being equally legitimate to the reader because they would refer respectively to the material essence or bundled nature of contents of the chest to which the label was originally attached, yielding the sense of 'implements', 'accessories', or 'instruments' in sundry material media. The signs below and after the determinative are faint but legible. The mm is either the genitive, treating hbsw as a masculine collective singular (e.g. 'kit'), or the immutable dative 'for'.

\section{LINE 2}

The fourth sign from the right is interpreted - from among several choices $-w_{1}$. This would place the strokes prior to instead of under or after it. Although odd, it conveniently forms a boxed 'group' of signs, leaving to carry the central meaning of the word to avoid confusion that there might be plural ceremonies. The present author has chosen to interpret this word as a generic term for the ritual for which the implements were assembled. The ritual is otherwise known specifically as the 'Opening of the Mouth', the word $h s . w$ therefore being the catch-all for the actions, singing, chanting, dancing, and presenting done comprehensively to prepare for the burial of those important enough to afford the proverbial bells and whistles of the final rites.

The amorphous vertical stroke which seems to follow the seated man is a shadow along the vertical ridge, and on the other side a darkened 'rut' multiplies the effect.

\section{LINE 3}

It is difficult to believe that $i(w) f$ refers to anything other than the wooden model of the ox-haunch, the remains of which were found in the tomb (exc. nos 99.98.0608-99.98.0609), ${ }^{6}$ although this concern would have been moot had it been referred to as the hpš instead of merely being documented in the label as 'meat'/'flesh'. It is untenable that real flesh would have been included with the chest of implements, for the perishable substance would

\footnotetext{
${ }^{6}$ Strudwick 2009: 230-231, Fig. 17; Strudwick (Ed.) 2016: 263, Fig. 221.
} 
otherwise have been provided fresh 'on the hoof' at the ceremony itself. Senneferi's tomb does contain real food, and it was packaged separately. ${ }^{7}$

An alternate interpretation of the line is to reconstruct it as iw.f twt(.w) 'which is complete', a virtual relative clause with qualitative. It is unlikely that the contents of the box would be construed grammatically as undefined, and orthographic emendations would be required. It is preferable to trust the scribe to write what he meant precisely and not leave the reader to 'interpret'. Instead, the author understands $t w t$ as a passive participle referring to the double subject 'accoutrements' and 'flesh', and to be translated as 'which are assembled', 'kitted out', or 'boxed up'. Similarly, the word could be nominalised and used to look forward to the next two lines, the translation then being, 'That which is assembled together: ...', a heading referring to the tally of lines 4 and 5 .

\section{LINE 4}

This line either commences a specific list of lines 4 and 5, or might continue '... completed (with) ...', though a preposition would be expected after twt. The tally of ' 9 ' must act as a noun and refer to the tools in general. If $t w t$ were to be interpreted as 'images', one would expect the '9' to follow it directly since there is room before the left edge of the label for the indication of quantity to fit nicely.

Note that the hieratic sign is indented as is line 5 directly below it. This phenomenon may indicate that these two lines are seen as the tally of the boxed kit or that the scribe thought the initial hieratic sign was too 'bulky' to write in the left margin and would have been awkwardly bisected by the vertical ridge.

The second sign group is difficult to discern because it appears initially to be a coneshape of pen swirls. But close inspection in false colour enhancement reveals that only the bottom line and perhaps the shorter one above it are caused by ink, thus a genitive $n$ or feminine n.t. Other 'false ink strokes' appear throughout the label, and are abrasions, nicks, and imperfections on the surface of the wood mimicking intentional text. The cone-shaped swirls might have occurred from the scribe trying to rub down the raised ridge on the undulating surface so he could make a long vertical sign more easily and recognisably.

The ensuing sign is rejected as $h m(. t)$ 'bronze' or $p h$ 'end' ${ }^{8}$ Because it is assumed to be $h b n y$, in contrast with $3 b w$ on the next line, ${ }^{9}$ one would expect a second 'handle' of the plough on the hieratic sign ${ }^{10}$ as well as an $n$ underneath the plough, the reason for the absences being perhaps that the scribe was practicing an economy of strokes for his crude label, defining the word by means of a simple stroke. Otherwise, long horizontal signs are nearly absent in the label due to its vertical raised ridges and undulating surface.

${ }^{7}$ Strudwick 2009: 30. Food containers and a bovid leg bone were found in the burial chambers (Strudwick (Ed.) 2016: 277-279).

${ }^{8}$ Merymery's tomb list (Leiden RMO AP. 6: Strudwick 2009: Fig. 6; Otto 1960: Fig. 14 [vol. II]) of Opening of the Mouth equipment mentions a iwf $n p h$, but this cannot be what the scribe of the current label has intended.

${ }^{9} \mathrm{~Wb}$ II, 487(10).

${ }^{10}$ Möller 1927: 42 sign 468 (giving no examples for the Eighteenth Dynasty). 
The identification of all nine items of ebony that were once contained in the kit to which the label was attached cannot be attempted from the remains the excavators found strewn in the tomb. Other implements for Senneferi's Opening of the Mouth ritual may have been included in a second box, for the finger (exc. no. 99.98.0648), censer handle (exc. no. 99.98.0650), the haunch (exc. nos 99.98.0608-99.98.0609), and two objects of unknown affinity (exc. nos 99.98.0640 and 99.98.0665; for the latter, see further below and Fig. 5) are of wood that the excavators have not identified, but does not, with the possible exception of exc. no. 99.98.0665, appear to be ebony.

\section{LINE 5}

The large blob between lines 4 and 5 appears under false colour enhancement to be some damage and shadowing as well as a substantial amount of ink. Perhaps the scribe wrote a sign in an attempt to commence line 5 in the right furrow only to realise that it would not continue contiguously across the pronounced ridge and then inked it out or tried to rub off the ink. In any case, the blob is now illegible, and the first sign on line 5 does require more horizontal space than the furrow at the right edge would allow.

The first signs on this line are written on a rough surface and have been damaged or worn but indicate unequivocally the presence of the imy-wt adze, one of the tools explicitly used in the Opening of the Mouth ceremony and attested by at least one fragment of its handle (exc. no. 99.98.0518) in TT99.

The hieratic sign beginning the word $3 b$ looks to be the 'standard' of $\frac{11}{4}$ rather than the 'chisel' $?$, but this is, in any case, an attested alternative writing.

The last group mimics clearly the hieratic for ' 20 ', but it must be that the tooth sign was written diagonally instead of horizontally above the stroke. This modification is again because of the troughs and ridges on the surface that do not favour the standard writing of long horizontal signs.

Whereas a fragment of a $w r-h k 3 . w$ adze (exc. no. 99.98.0601), a putative member of the ceremonial kit, was found in the tomb, it is not recorded on the label. Since the inclusion of such a precious item could hardly have been forgotten, it is better to presume that it was packed separately.

\section{CONTEXT AND DISCUSSION OF THE LABEL AND THE RITUAL}

There can be little doubt that the recognition of the text on this label goes a considerable way to rounding off the speculation in Strudwick's article that a collection of ritual implements was buried with Senneferi. Again, this shows that much is to be gained from careful excavation, analysis and study of what initially appears to be unpromising contexts. ${ }^{12} \mathrm{~A}$ few outstanding points remain to be considered.

\footnotetext{
${ }^{11}$ Möller 1927: 52 sign 578 (giving no examples for the early Eighteenth Dynasty).

${ }^{12}$ Strudwick 2009: 236.
} 


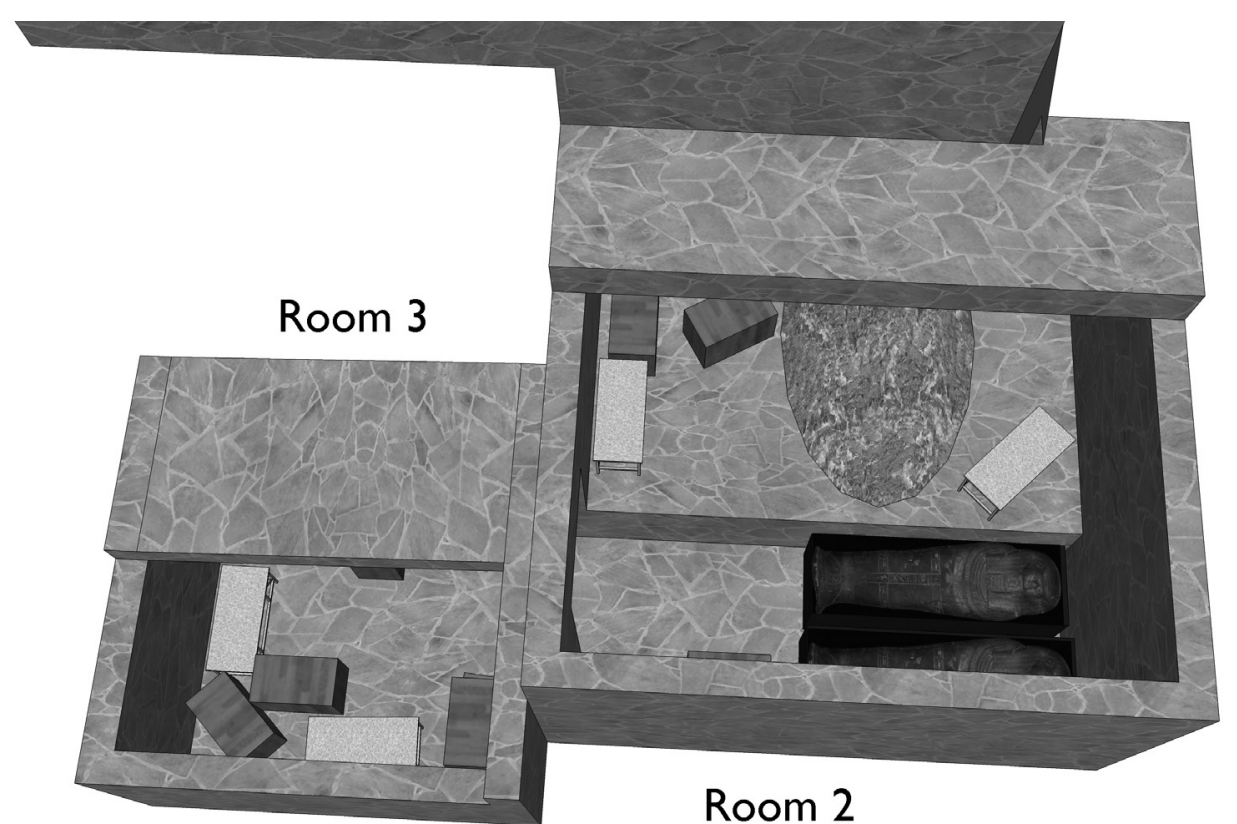

2. Schematic 3D model of TT99 Shaft I burial chambers, Rooms 2 and 3 (C H. Strudwick).

\section{THE CONTEXTUAL RELATIONSHIP OF THE LABEL TO THE REST OF THE ASSEMBLAGE}

As indicated, the label was found in Room 3 of Shaft I. Shaft I is the deep vertical shaft in the courtyard of TT99 from which leads one long corridor (Corridor 1), a short corridor turning to the left (Corridor 2), at the end of which is a room (Room 1). In the floor of Corridor 2 was cut a small rough shaft which was termed the 'Staircase shaft' as its roughhewn appearance initially suggested it might have been intended as a short stairway. At the bottom was a roughly square room (Room 2), in the floor of which lay an intriguing depression leading into Room $3 .{ }^{13}$ A very schematic $3 \mathrm{D}$ diagram of the latter two chambers will be found as Fig. 2. ${ }^{14}$

No item has yet been found away from the spill from the emptying and refilling of the main shaft which cannot be attributed to the Eighteenth Dynasty and many of the fragments found bore the name or titles of Senneferi, so there is no doubt that he was buried here. Helen and Nigel Strudwick have reconstructed the burials in these chambers to include those of Senneferi, his wife Taiamu, his parents Haydjehuty and Satdjhuty, and possibly a young daughter(?). ${ }^{15}$ Most of the different categories of object, including the remarkable ceramic assemblage, ${ }^{16}$ were predominantly found in Rooms 2 and 3, suggesting that they

\footnotetext{
${ }^{13}$ See sketch plan, Strudwick 2009: 215, Fig. 1.

${ }^{14}$ Note that the positioning of objects in the chambers is purely illustrative.

${ }^{15}$ See: Strudwick (Ed.) 2016: 77-83, for a summary of the history and construction sequence and usage of the chambers.

${ }^{16}$ An overview of this forms part of Rose 2003, with full detail in Rose 2016.
} 
were where Senneferi was buried; most likely, due to size, Room 2 was the location of the coffins, and Room 3 was a storeroom.

The specific locations of the objects that have been associated with the Opening of the Mouth ritual are given in Table $\mathbf{1}$ below.

Tab. 1. Opening of the Mouth objects from TT99 Shaft I

\begin{tabular}{|c|c|c|c|c|}
\hline & Find spot & References & Otto scene ${ }^{17}$ & $\begin{array}{l}\text { Merymery } \\
\text { item }^{18}\end{array}$ \\
\hline Adzes (various) & Room 3 & Strudwick 2009: 214-218, Figs 2-5 & $26,27,46$ & $15-19$ \\
\hline Finger & Room 3 & Strudwick 2009: 230-231, Fig. 18 & $14,32,33$ & 13 \\
\hline Model ox leg (hpš) & Room 2/3 (join) & Strudwick 2009: 230-231, Fig. 17 & 24,45 & In preamble \\
\hline Censer & Room 3 & Strudwick 2009: 232-233, Fig. 20 & $\begin{array}{l}6,47,59 A, 60 \\
61,64,66,71\end{array}$ & $20-22$ \\
\hline Uncertain items & Room 3 & $\begin{array}{l}\text { 1. Strudwick 2009: 231-232, Fig. } 19 \\
\text { 2. see: Appendix }\end{array}$ & & \\
\hline Ostraka & $\begin{array}{l}\text { Room } 2 / 3, \\
\text { Staircase shaft } \\
\text { and Corridor }\end{array}$ & Strudwick 2009: 233-234, Fig. 21 & & \\
\hline Label & Room 3 & see above & & \\
\hline Box $\mathrm{H}$ fragment & Room 3 & see: Appendix & & \\
\hline Box A (possible) & $\begin{array}{l}\text { Room 3, } \\
\text { Corridor }\end{array}$ & Strudwick 2009: 234, Fig. 22 & & \\
\hline
\end{tabular}

It is evident from this that the bulk were found in Room 3, logical if it were a storeroom. The possibility cannot be excluded that their container was in Room 2 and cast into Room 3 after ransacking by robbers. As ever, we are hampered by the lack of intact comparable tombs and by the lack of parallels to these objects, although some indication of the layout might be given by the bipartite division of the burial chamber of Yuya and Tjuya, with the coffins in the main chamber (which would be our Room 2) and the ceramics mainly at the far end, with some other burial goods. ${ }^{19}$

\section{TO WHAT WAS THE LABEL ATTACHED?}

Could the label have been attached to a box in the assemblage? None of the fifteen comparable labels in the tomb of Tutankhamun published by Černý were still attached

\footnotetext{
${ }^{17}$ Following Otto 1960. These include every possible related scene (thus every adze and every possible chisel), and not just the specific ones noted in Strudwick 2009.

${ }^{18}$ Leiden RMO AP.5. See: Strudwick 2009: Fig. 6; Otto 1960: Fig. 14 (vol. II).

${ }^{19}$ Reeves, Wilkinson 1996: plan on p. 176.
} 
to a container, but were rather '[f]ound scattered all over the floor of the tomb' ${ }^{20}$ As observed above, no contemporary examples are known to us from private tombs. ${ }^{21}$ The location of the Tutankhamun examples apart from their boxes can be explained by their having been tied to a knob on the lid of a chest or the corresponding knob located on the side of the box. When the box was secured, string ran from one knob to the other and would have borne a clay or wax seal to keep the string from being tampered with. The label would have been attached by the same string or a loop of another string to one of the knobs. The rapid and opportunistic robberies in the tomb no doubt explain their find spots. ${ }^{22}$ When the robbers cut the string or roughly ripped the lid apart, the label would have been jettisoned. While the priests tidying up Tutankhamun's Annexe hurriedly re-stuffed boxes, they wrote the contents of the boxes in ink on the lids and usually near the securing knobs, where the information would be expected. In fact, a sixteenth roundtopped label is described in Carter's index cards with the words 'This came from the knob at one end of the chest. ${ }^{23}$

Three box knobs were found in TT99. ${ }^{24}$ A possibility for the original location of the TT99 label is that it was hanging from the string that may have wrapped around the lid and side knobs on the exterior of a chest, the remains of which are now either Box $\mathrm{H}$ or Box $\mathrm{A}$ in the table above (and Appendix below for Box $\mathrm{H}$ ). ${ }^{25}$

The excavators record that pieces of other boxes were also found, though none of these other fragments or boxes bear any indication that they were made specifically to contain ritual items for the Opening of the Mouth ceremony.

The label refers to a set of ten objects, nine of ebony (not further specified) and specifically the imy-wt adze; the next section of the present paper comments to some extent about the other items which might have been there, none of the surviving ones of which is clearly made of ebony. It seems that Senneferi's Opening the Mouth tools may have come in multiple packages, which might have included items later stolen from the tomb. Another option is that the extant label was attached to a cloth bag with a subset of items, and it might have been that this and any other such bags were placed inside a box as discussed above. ${ }^{26}$ A possible bag of kohl is shown inside a box or basket in TT217 (Fig. 3), and four somewhat cryptic references among the hieratic inscriptions in the tomb of Tutankhamun refer to boxes, the contents of which included tnfy.t hm. ${ }^{\complement} n h(. w) w d \underline{d}(. w) s n b(. w)$ ti $s w$

\footnotetext{
${ }^{20}$ Černý 1965: 15.

${ }^{21}$ Peter F. Dorman has assured Strudwick (personal communication) that no similar items are known from the tomb of Ramose and Hatnefer, the parents of Senenmut. A number of wooden labels seemingly of the Eighteenth Dynasty have recently come to light in KV40, but these appear to be name labels rather than those indicating contents of boxes or jars (Bickel, Paulin-Grothe 2014).

${ }^{22}$ Reeves, Wilkinson 1996: 68.

${ }^{23}$ Černý 1965: $10 \S 51$.

${ }^{24}$ Strudwick (Ed.) 2016: 283, Figs 253-254.

${ }^{25}$ An illustration of Box A is to be found in Strudwick 2009: 234, Fig. 22 and in Strudwick (Ed.) 2016: Fig. 245.

${ }^{26}$ A possible bag of Middle Kingdom tools seems to have been found in an unclear context at Deir Dronka (Kamal 1916: 95 (110)).
} 


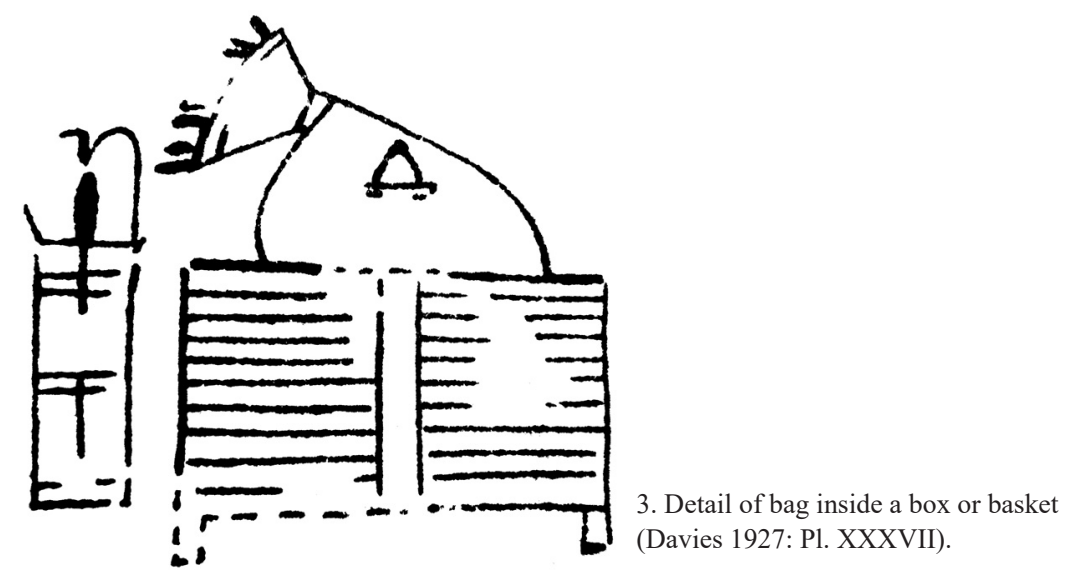

m inpw, perhaps 'bag of his majesty lph when he was a youth'.${ }^{27}$ It seems reasonably clear that tnfy.t refers to a bag or similar; one is shown in the tomb of Ay at Amarna, ${ }^{28}$ and some sort of sack or sacking, termed tnfy.t, is brought to the luckless soldier in Papyrus Lansing. ${ }^{29}$

It is noteworthy that the imy-wt adze appears specifically on the TT99 label (and in Merymery's list), but not in Otto's synthesis of the Opening of the Mouth ritual. ${ }^{30}$ Was it kept separate (in TT99's case) from the other Opening of the Mouth instruments for some reason? Or is it just an accident of preservation? Some further remarks are made in the next section of the present paper.

\section{Some comments on the Opening of the Mouth Ritual of Senneferi}

\section{SUMMARY OF THE EVIDENCE FROM TT99}

The tomb of Senneferi contains a wider range of local references to the ritual than most, perhaps all, tombs of the early part of the Eighteenth Dynasty. These fall into four sub-groups.

A. The objects from the burial are considered above and in a previous publication. ${ }^{31}$

B. Wall 16, the rear room or shrine of the tomb, north-west wall, shows the deceased and his wife Taiamu receiving libations, and is described as 'Creating ( $m s t)$ the Opening of the Mouth in the mansion of gold (hwt nwb)' (Fig. 4). ${ }^{32}$ The actual words then spoken are the common libation formula to Horus, Seth, Thoth and Dunanwy, the origins of

${ }^{27}$ Černý 1965: 9-10 (50), 13 (57), 14 (59), 15 (63); the first three are on boxes, the fourth on one of the wooden labels. The word tnfy.t will be found in $W b$ V, 380-381 and is considered on Černý 1965: 10.

${ }^{28}$ Davies 1908: 23, Pl. XXX (lower right).

${ }^{29}$ pLansing 10,8: Gardiner 1937: 109.

${ }^{30}$ As noted in Strudwick 2009: 222.

${ }^{31}$ Strudwick 2009.

${ }^{32}$ Strudwick (Ed.) 2016: 137-138, Pl. 37, Colour Pls 27B, 28A. 
which go back to the Pyramid Texts. The other half of the same scene shows another priest making a htp-di-nswt-offering. ${ }^{33}$

C. The remains of the Opening of the Mouth ritual in the more usual form of 'Rites before mummies' are evident in at least two sub-registers on the same wall. ${ }^{34}$

D. A scene showing Senneferi receiving his funerary equipment, amongst which are a number of items that may have been used for this particular ritual, is depicted on the south wall of the passage (Wall 9). In particular there are a number of staves and sceptres, and also nms.t- and dšr.t-vessels. ${ }^{35}$

Of the above, A. is presently unknown elsewhere in Thebes, while C. is rather common. D. is only known in two other tombs, TT79 ${ }^{36}$ and TT85, ${ }^{37}$ and B. seems to have no exact parallel in a Theban tomb of the first half of the Eighteenth Dynasty, although there is also an individual scene of a priest performing the ritual in TT85, albeit with empty text columns. ${ }^{38}$

\section{WHAT WAS THE ROLE OF THE PHYSICAL OBJECTS?}

Stylised adzes and wooden ox-legs make it evident that the Opening of the Mouth objects found in the burial of Senneferi are not simply 'everyday' items transferred into a funerary context. ${ }^{39}$ Were they the actual objects used in the full ritual, later buried with the deceased, or were they specially made to be placed in the burial chamber to ensure the effective continuation of the ritual (or possibly even a combination of both)?

The wooden ox-leg is obviously a model or imitation ${ }^{40}$ with a symbolic role to represent an item in the ritual. With slaughtering scenes and the presentation of ox-legs playing a prominent role in the Opening of the Mouth, ${ }^{41}$ it seems quite possible that a real ox might have met its demise in the ceremony, and so it is cautiously suggested that this item might have been primarily intended for burial, where its form would not be affected by the passage of time. ${ }^{42}$

\footnotetext{
${ }^{33}$ The location of these scenes on Wall 16 is unusual for tombs of this date (Engelmann-von Carnap 1999: 229).

${ }^{34}$ Strudwick (Ed.) 2016: 140-141, Pl. 35C-D, Colour Pl. 29A-B.

${ }^{35}$ Strudwick 2009: 225, Fig. 15 and table on p. 238; PM I², 205 (8); Strudwick (Ed.) 2016: 118-120, Pl. 31A, Colour P1. 19B.

${ }^{36}$ Guksch 1995: 164-165.

${ }^{37}$ Strudwick 2009: Fig. 14.

${ }^{38}$ Strudwick 2009: Fig. 13.

${ }^{39}$ Strudwick 2009: 219-220.

${ }^{40}$ Various terms can be used by scholars to refer to any objects that they consider as either smaller than 'everyday' items or have a role other than that which might have been envisaged for the supposed 'everyday' originals. The four that come to mind are 'model', 'miniature', 'imitation' and 'dummy', each with its own range of meaning. Without entering into what would surely be a tedious discussion of the similarities and differences, caution should be exercised as to how these terms are applied.

${ }^{41}$ Assmann 2001: 314-326, including the later scene of removal of the foreleg of a calf.

${ }^{42}$ Note that a real bovid bone was found in the burial chamber of TT99 (Strudwick (Ed.) 2016: 279,
} Fig. 241). 


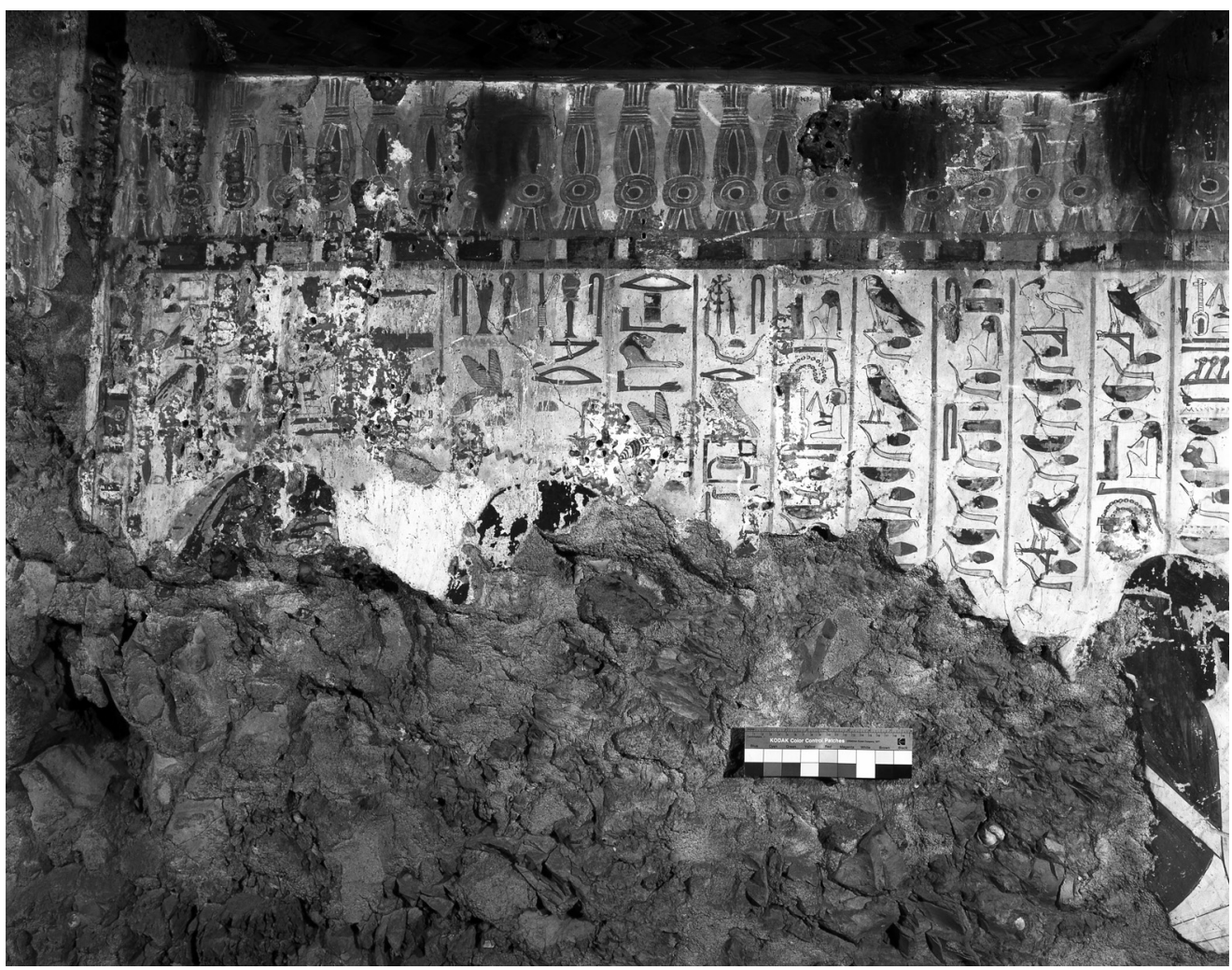

4. TT99, Wall 16, couple receiving libation (Phot. A. Middleton (C N. Strudwick).

The stylised adzes, however, long before diverged from their 'real' counterparts ${ }^{43}$ and if Strudwick's reconstruction of the TT99 adzes is correct, estimated as having a length of about $26.5 \mathrm{~cm},{ }^{44}$ then there is every possibility that they could have been actually used in the ritual as well as being buried for their magical powers, although, since it is an object used for its symbolic power, the size actually does not matter.

The finger of electrum is again symbolic, and could be both used and then buried, and it would seem that the censer was likewise large enough to have held a copper bowl in which incense could have easily been burned. On balance, there is no reason to assume that the objects found in TT99 could not have been used for the ceremonies before burial and then interred with the deceased.

It is intriguing how relatively few Opening of the Mouth objects there are from TT99 when compared to those in the Saqqara list of Merymery (Leiden RMO AP.6) ${ }^{45}$ Even

\footnotetext{
${ }^{43}$ Roehrig, Dreyfus, Keller (Eds) 2005: 141-146, especially compare Cat. 76e with 76k on pp. 144-145. Both types are evident in Middle Kingdom object friezes (Jéquier 1921: 274).

${ }^{44}$ Strudwick (Ed.) 2016: 262-263; this makes it similar in size to the objects just noted in Roehrig, Dreyfus, Keller (Eds) 2005

${ }^{45}$ Strudwick 2009: Fig. 6; Otto 1960: Fig. 14 (vol. II).
} 
when the Leiden list is contrasted with the better-preserved Twenty-sixth Dynasty set of Tjaenhebu, ${ }^{46}$ there are still considerably more items in the Merymery relief, especially when it is considered that the Saite find included a number of staffs and sceptres which are not in the Leiden list. However, the Leiden list seems to be unique, and there are many elements in it that cannot be equated with known elements of the ritual as depicted in the long sequences in, for example, the tomb of Rekhmire or that of Sety I, used by Otto in his presentation and interpretation of the whole ritual. ${ }^{47}$ Some of these elements could easily have been present and either stolen, destroyed or decayed and thus not recognised as such in TT99 by the excavator.

The label forming the principal subject of this paper refers to nine items of ebony, although objects made of that wood have not yet been identified from the surviving material. The uncertain item in the Appendix below (exc. no. 99.98.0665) could, however, be one of these. The Merymery list only mentions one item made of ebony ( $h b n y)$, the $m \underline{d} 3 . t,{ }^{48}$ which bears a chisel image at the bottom of its list compartment, and no certain such object has yet been identified from TT99. ${ }^{49}$ Attention was drawn above (see p. 113) to the singular mention of the imy-wt adze on the wooden label without a corresponding reference to the other adze found in TT99, the $w r-h k 3 w$. These were the only two adzes found, and such large elaborate ivory objects were surely expensive. Perhaps there was also a second bag or box of Opening the Mouth items of which the $w r-h k 3 w$ was the principal item?

The Merymery list clearly needs further study, but the Senneferi material has much more in common in its scope with the usual repertoire of Opening of the Mouth items, as they appear in scenes in tomb decoration and papyri.

\section{HOW WERE ITEMS POSITIONED IN THE BURIAL?}

Evidence is somewhat limited for ritual objects that were actually buried with the dead and that can be directly linked with any of the many rituals which may have been enacted in the course of Egyptian history. ${ }^{50}$ However, these few examples cover much of the span of Egyptian history, although the finds from TT99 are the sole clear evidence from an Eighteenth Dynasty private tomb. ${ }^{51}$

Miniature or model ceramic vessels have been found in the entrance to burial chambers of Old Kingdom mastabas, suggesting that elements of the offering ritual were enacted there

\footnotetext{
${ }^{46}$ Strudwick 2009: 223-225, referring to Bresciani et al. 1977: 68-74.

${ }^{47}$ Otto presents the elements of the Merymery list with equations to his scene list in Otto 1960: 22-26 (vol. II), and emphasises the problems that this creates. The principal equivalences are tabulated in Strudwick 2009: 236-238.

${ }^{48}$ Otto 1960: 20, 25, 164 (vol. II); the latter page quotes Coffin Texts CT III, 299, where it is made of copper (bi3).

${ }^{49}$ Strudwick 2009: 231-232, Fig. 19 identified object exc. no. 99.98 .0665 as a possible chisel handle, but, following a discussion with Geoffrey Killen in March 2016, that identification seems unlikely.

${ }^{50}$ See Assmann 2001: Part II for an overview of the textual evidence for the range of rituals known; it cannot of course be determined with any certainty how many of these were performed in an particular instance.

${ }^{51}$ Note however two possible C $b t$ objects from the tomb of Maya and Merit at Saqqara (Strudwick 2009: 228-230).
} 
in addition to those that may have taken place on top of the mastabas themselves. ${ }^{52}$ Evidence of a series of more clearly recognisable rituals was found in 2012-2013 in a burial chamber in the tomb of Djehutynakht (I?) at el-Bersha, ${ }^{53}$ where the excavator has identified several distinct phases, including offering and libation rituals and, most relevant here, a form of the Opening of the Mouth. ${ }^{54}$ Coming from the reign of Amasis in the Twenty-sixth Dynasty is the remarkable find of Opening of the Mouth equipment in the tomb of Tjaenhebu (noted above). These objects, which range from adzes, through model vessels of stone, to a range of sceptres and wands, were found in a box blocking the doorway at the entrance to the sarcophagus chamber at the bottom of one of the vertical shafts so characteristic of this date. ${ }^{55}$

From this very limited range of sources, it seems that, where space was available in the burial chamber, as seen in the Old and Middle Kingdom tombs, ritual objects were certainly placed near the entrance of the burial chamber. In the case of the tomb of Djehutynakht (I?), objects were laid out from the chamber entrance to the end of the coffin. Moving later, Tjaenhebu's burial party probably had little choice but to leave his box of Opening the Mouth equipment in the entrance to the chamber as space in these Saite and Persian shaft burials was very limited.

Model or miniature ritual objects were clearly the rule from these examples, all later or earlier than the New Kingdom. Is it significant that excavators have not reported finding miniature ceramics of any description in these burials after the Old Kingdom? The same is true of TT99, ${ }^{56}$ where there are also no signs of any miniature vessels of any type. Strudwick has searched carefully through the other funerary goods preserved in fragments in the burial chambers of TT99 and nothing is immediately apparent. Senneferi was buried with a number of full-size stone vessels, but these actually contained oils $;{ }^{57}$ similarly, the pottery discovered is of the storage type, containing, at a minimum, wine and various seeds and nuts to judge from both the labels on some vessels and the sheer size of many of them. ${ }^{58}$

\footnotetext{
${ }^{52}$ Alexanian 1998, with evidence for the rituals at the entrance to the burial chambers on pp. 11-18; see: Alexanian 1999: 110-114, Figs 47-48 for a specific example.

${ }^{53}$ Willems 2016. I would like to thank Harco Willems for permitting me to see a copy of this paper in advance of publication, and for discussing it with me after two lectures in Cambridge and Cairo.

${ }^{54}$ Willems 2016: 162-168. In particular, his identification of model tools in the burial chamber as indicative of the later stylised adzes in the Opening of the Mouth ritual is new; he compares them with the better-preserved box of Ankhef in the Metropolitan Museum (Hayes 1953: 288, Fig. 189). Given how it is speculated above that some of the items in TT99 might have been placed in a bag, the mention of a bag of tools from a possible Middle Kingdom context at Deir Dronka is intriguing (Kamal 1916: 95 (110)).

${ }^{55}$ Barsanti 1900: 263; Bresciani et al. 1977: 68.

${ }^{56}$ There is at present little evidence for miniature vessels, stone or pottery, in any New Kingdom burials at Thebes. Almost all those that have been clearly identified come from foundation deposits in temples or royal tombs, and are ceramic (for example, deposits of Hatshepsut (Carnarvon, Carter 1912: 31, Pl. XXII), in the tomb of Amenhotep III (Reeves, Wilkinson 1996: 28) and the tomb of the Three Princesses, (Lilyquist 2003: 62, Fig. 28). The one published exception to this is a selection from the German Archaeological Institute excavations in two shaft tombs in the 'lower class' cemetery at Dra Abul Naga, where the author groups them with cult ceramics (Seiler 1995: 187, 196-198 and Fig. 5, referring to finds in tombs K 91.5 and K 91.7). No information about their exact location is yet available in the preliminary reports (Polz 1993: 231-232, Figs 3-4).

${ }^{57}$ Strudwick (Ed.) 2016: 273-276.

${ }^{58}$ This material is studied in: Bohleke 2016.
} 


\section{AVENUES FOR FURTHER RESEARCH}

Senneferi's wall scenes include one of the relatively few tomb depictions of a rite of Opening of the Mouth in the hwt nwb, usually regarded as part of the craftsmen's workshop, where rituals were performed on a statue. ${ }^{59}$ The exact context of this particular scene needs further clarification as to whether this is indeed a statue or tomb ritual (or both), ${ }^{60}$ and whether the term $h w t n w b$ holds any further significance. ${ }^{61}$

The term wsht also merits further examination. Tomb scenes and papyri later than TT99, beginning around the reign of Amenhotep III, appear to show the Opening of the Mouth taking place in the tomb courtyard with the expressed need to expose the mummy to the sun. ${ }^{62}$ Much depends here on the use of $w s h t$, the term applied to the location where the ritual takes place in these later texts. It can refer both to a hall (usually enclosed) and a court (usually not). ${ }^{63}$ No real work has been done to ascertain exactly what wsht indicates in a tomb, as opposed to a temple context, ${ }^{64}$ but there are clear cases where it is applied to a room in a tomb. ${ }^{65}$ It should also be remembered that the conventions of Egyptian two-dimensional art would make it very difficult to distinguish a ritual taking place inside a tomb from one outside.

So far, Senneferi's Opening of the Mouth equipment is the only set known from a tomb in the Theban Necropolis. Was his desire to be buried with these objects unique - was it his own preference, a passing fashion, or is it again an accident of preservation?

\section{APPENDIX: TWO FURTHER POSSIBLE OPENING OF THE MOUTH ITEMS FROM TT99}

\section{UNCERTAIN WOODEN ITEM (EXC. NO. 99.98.0665) (Fig. 5) ${ }^{66}$}

Dimensions: L $16.5 \mathrm{~cm}, \mathrm{~W} 4.5 \mathrm{~cm}$, Th $3.5 \mathrm{~cm}$.

A shaped piece of hard wood, which tapers and has a round end. Its purpose is uncertain, but as well as being part of a regular piece of furniture, on the basis of the presence of the fragments mentioned in Strudwick 2009, it could be another object associated with the Opening of the Mouth ritual. The suggestion is made in the text above that it could have been made of ebony, but further analysis would be needed to confirm this. After

\footnotetext{
${ }^{59}$ Otto 1960: 3, 5 (vol. II).

${ }^{60}$ Otto 1960: 29-39 (Type 3) (vol. II).

${ }^{61}$ Gardiner raised the possibility, which he ultimately rejected, that hwt $n w b$ might also refer to a shrine or cult centre in a tomb (Davies, Gardiner 1915: 57-58 with p. 58 n. 1).

${ }^{62}$ See Assmann 2001: 299-329, with the Opening of the Mouth elements on pp. 310-329. More detail of many of the sources will be found in Bartelmeß 1992: 93-113.

${ }^{63} \mathrm{~Wb}$ I, 366.

${ }^{64}$ Its use in temple terminology covers both covered and uncovered areas, although the halls are usually of the pillared type (Spencer 1984: 71-80, 88, 89).

${ }^{65}$ Such as in the break-in to the tomb of Sebekemzaf described in the pAbbott (Peet 1930: Pl. II (Abbott 3, 1. 3) or in the Turin plan of the tomb of Ramesses IV (Carter, Gardiner 1917: 138, Pls XXIX-XXX).

${ }^{66}$ Strudwick (Ed.) 2016: 263, Fig. 225.
} 

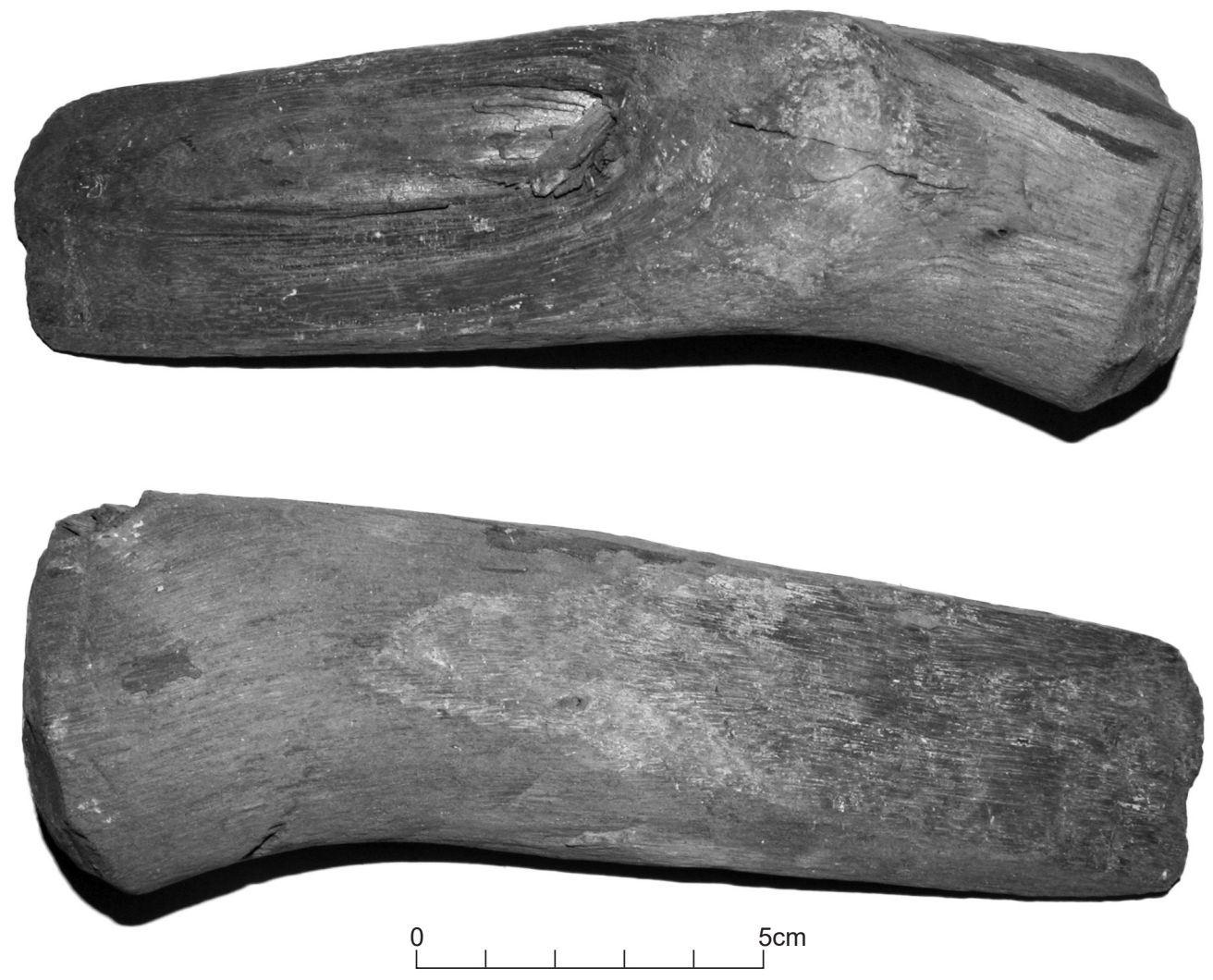

5. Uncertain wooden item, exc. no. 99.98.0665 (Phot. C N. Strudwick).

a photograph of this object was examined by Geoffrey Killen, he suggested that the large rounded end and tapered other end might indicate it was a handle for an object, perhaps even one of the ivory adzes mentioned above. ${ }^{67}$

\section{Probable Wooden boX Fragment (EXC. NO. 99.98.0658) (Fig. 6) ${ }^{68}$}

This fragment is termed part of 'Box H'. Dimensions: L $4.6 \mathrm{~cm}, \mathrm{~W} 2.4 \mathrm{~cm}$, Th $0.7 \mathrm{~cm}$.

Small fragment of box with carved sunk hieroglyphs filled with blue paint. The surviving signs read: ... $k r . k$ and ... z3.k. The wood is thinner and more delicate than that used for the others in the tomb. Such thin walls are characteristic of small boxes, used for jewellery or toilette items, ${ }^{69}$ or may just be thinner wood used for a lid.

\footnotetext{
${ }^{67}$ Personal communication, March 2016.

${ }^{68}$ Strudwick (Ed.) 2016: 268, Fig. 228.

${ }^{69}$ Such as MMA 36.3.199 and University of Pennsylvania E 14198 (Roehrig, Dreyfus, Keller (Eds) 2005: 254-255 (187-188)) or two boxes found in the Carnarvon excavations in Thebes (Carnarvon, Carter 1912: 53,
} 
6. Probable wooden box fragment, exc. no. 99.98.0658 (Phot. A. Middleton (C) N. Strudwick).

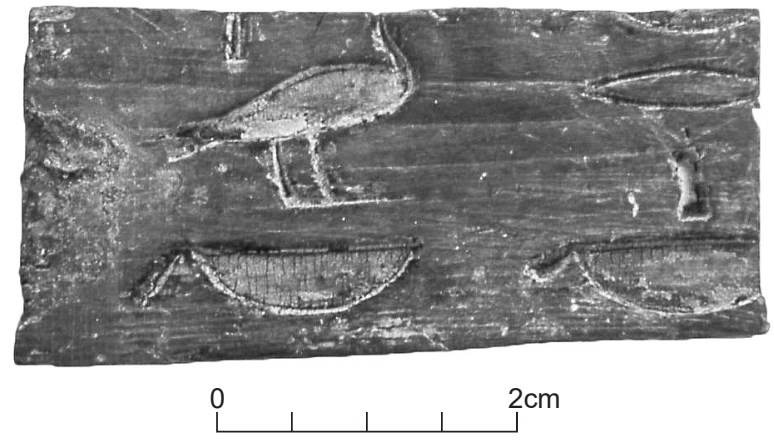

The fragmentary texts perhaps suggest the purpose of this box. $r . k$, 'your mouth', in the first column evokes the Opening of the Mouth ritual, and it is most likely that the traces above the $\prec$ are the bottom of the $ひ$ sign, giving 'opening for you your mouth', found ubiquitously throughout the ritual. The reference to $z 3 . k$ in the other column will, following the same line, be a reference to the son of the deceased - or otherwise 'the beloved son' whose role, when not taken by other priests, is an essential one in the ritual. ${ }^{70}$ No parallels to this fragment have so far been noted.

\section{Acknowledgments}

Nigel Strudwick would like to thank Geoffrey Killen for his thoughts on some of the wooden objects, Hans-Hubertus Münch for drawing the labels in KV22 to our attention, and especially to Helen Strudwick for reading multiple drafts of his part of the manuscript and for creating the 3D schematic model of the burial chambers.

\section{References}

Alexanian, N. 1998: Ritualrelikte an Mastabagräbern des Alten Reiches, [in:] Guksch, H., Polz, D. (Eds), Stationen: Beiträge zur Kulturgeschichte Ägyptens, Rainer Stadelmann gewidmet, Mainz a/Rhein 3-22

Alexanian, N. 1999: Dahschur II. Das Grab des Prinzen Netjer-aperef. Die Mastaba II/1 in Dahschur, ArchVer 56, Mainz a/Rhein

Assmann, J. 2001: Death and Salvation in Ancient Egypt, trans. Lorton, D., Ithaca

Barsanti, A. 1900: Tombeau de Zannehibou, ASAE 1, 262-271

Pls XLV (1), XLVI (1)). Such small boxes do not typically bear hieroglyphs; one example which does, but is probably a different type to those mentioned previously as it contained a loincloth, is that of Maherpri, Boston MFA 03.1036ab (Roehrig, Dreyfus, Keller (Eds) 2005: 74).

${ }^{70}$ Otto 1960: 36 [Spell 14c], 103 [Spell 45c] (vol. I); 13, 65-66 [Spell 14c], 106 [Spell 45c] (vol. II). Note

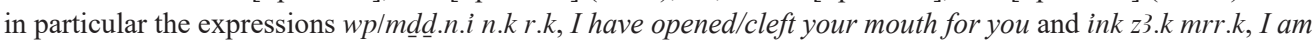
your beloved son. In each scene the lector priest is reading while the sem-priest either uses his small finger or the khepesh-leg to open the mouth. 
Bartelmeß, P. 1992: Der Übergang ins Jenseits in den thebanischen Beamtengräbern der Ramessidenzeit, SAGA 2, Heidelberg

Bickel, S., Paulin-Grothe, E. 2014: KV 40: a burial place for the royal entourage, EgArch $45,21-24$

Bohleke, B. 2016: The hieratic jar labels, [in:] Strudwick, N. (Ed.), The tomb of Pharaoh's Chancellor Senneferi at Thebes (TT99), Oxford, 239-259

Bresciani, E., Pernigotti, S., Giangeri Silvis, M.P. 1977: La tomba di Ciennehebu, capo della flotta del re, Tombe d'età saitica a Saqqara I, Pisa

Carnarvon, Earl of, Carter, H. 1912: Five Years' Explorations at Thebes. A Record of Work Done 1907-1911, London

Carter, H., Gardiner, A.H. 1917: The Tomb of Ramesses IV and the Turin Plan of a Royal Tomb, JEA 4/2-3, 130-158

Černý, J. 1965: Hieratic Inscriptions from the Tomb of Tut'ankhamūn, TTSO 2, Oxford

Davies, N. de G. 1908: The rock tombs of el Amarna VI. Tombs of Parennefer, Tutu and Aÿ, ASEg 18, London

Davies, N. de G. 1927: Two Ramesside Tombs at Thebes, RPTMS 5, New York

Davies, N. de G., Gardiner, A.H. 1915: The Tomb of Amenemhēt, No. 82, TTS 1, London

Engelmann-von Carnap, B. 1999: Die Struktur des thebanischen Beamtenfriedhofs in der ersten Hälfte der 18. Dynastie: Analyse von Position, Grundrißgestaltung und Bildprogramm der Gräber, ADAIK 15, Berlin

Fitz Museum: http://www.fitzmuseum.cam.ac.uk/tt99/ (accessed November 1, 2016)

Gardiner, A.H. 1937: Late-Egyptian Miscellanies, BiAeg 7, Bruxelles

Guksch, H. 1995: Die Gräber des Nacht-Min und des Men-cheper-Ra-seneb Theben Nr. 87 und 79, ArchVer 34, Mainz a/Rhein

Hayes, W.C. 1953: The Scepter of Egypt: A Background for the Study of the Egyptian Antiquities in The Metropolitan Museum of Art I: From the Earliest Times to the End of the Middle Kingdom, New York

Jéquier, G. 1921: Les frises d'objets des sarcophages du Moyen Empire, MIFAO 47, Le Caire

Kamal, A.B. 1916: Fouilles à Deir Dronka et à Assiout, ASAE XVI, 65-114

Lilyquist, C. 2003: The Tomb of Three Foreign Wives of Tuthmosis III, New Haven-London

Möller, G. 1927: Hieratische Paläographie: die ägyptische Buchschrift in ihrer Entwicklung von der fünften Dynastie bis zur römischen Kaiserzeit II: von der Zeit Thutmosis' III bis zum Ende der einundzwanzigsten Dynastie, Leipzig

Otto, E. 1960: Das altägyptische Mundöffnungsritual, $\ddot{A g} A b h$ 3, Wiesbaden

Peet, T.E. 1930: The Great Tomb-Robberies of the Twentieth Egyptian Dynasty: Being a critical study, with translations and commentaries, of the papyri in which these are recorded, Oxford

Polz, D. 1993: Bericht über die 2. und 3. Grabungskampagne in der Nekropole von Dra' Abu el-Naga/Theben-West, MDAIK 49, 227-238

Reeves, N., Wilkinson, R.H. 1996: The Complete Valley of the Kings: Tombs and Treasures of Egypt's Greatest Pharaohs, London 
Roehrig, C.H., Dreyfus, R., Keller, C.A. (Eds) 2005: Hatshepsut: from Queen to Pharaoh, New Haven-London

Rose, P. 2003: Ceramics from New Kingdom tombs: recording and beyond, [in:] Strudwick, N., Taylor, J.H. (Eds), The Theban Necropolis. Past, Present and Future, London, 202-209

Rose, P. 2016: The ceramics from Shaft I, [in:] Strudwick, N. (Ed.), The tomb of Pharaoh's Chancellor Senneferi at Thebes (TT99), Oxford, 191-238

Seiler, A. 1995: Archäologisch faßbare Kultpraktiken in Grabkontexten der frühen 18. Dynastie in Dra' Abu el-Naga/Theben, [in:] Assmann, J., Dziobek, E., Guksch, H., Kampp, F. (Eds), Thebanische Beamtennekropolen. Neue Perspektiven archäologischer Forschung, SAGA 12, Heidelberg, 185-203

Serpico, M., White, R. 2000: Oil, fat and wax, [in:] Nicholson, P.T., Shaw, I. (Eds), Ancient Egyptian Materials and Technology, Cambridge, 390-429

Spencer, P. 1984: The Egyptian Temple. A Lexicographical Study, London

Strudwick, N. 2000: The Theban Tomb of Senneferi [TT.99]. An overview of work undertaken from 1992 to 1999, Memnonia XI, 2000, 241-266

Strudwick, N. 2009: True "Ritual Objects" in Egyptian private tombs?, [in:] Backes, B., Müller-Roth, M., Stöhr, S. (Eds), Ausgestattet mit den Schriften des Thot. Festschrift für Irmtraut Munro zu ihrem 65. Geburtstag, SAT 14, Wiesbaden, 213-238

Strudwick, N. (Ed.), 2016: The tomb of Pharaoh's Chancellor Senneferi at Thebes (TT99), Oxford

Willems, H. 2016: Die Grabkammer Djehutinakht (I.?) in Dayr al-Barshā-methodologische Aspekte der Rekonstruktion des Ablaufs des Bestattungsrituals anhand eines neuentdeckten Beispiels, [in:] Pries, A.H. (Ed.), Die Variation der Tradition. Modalitäten der Ritualadaption im Alten Ägypten. Akten des Internationalen Symposions vom 25.-28. November 2012 in Heidelberg, OLA 240, Leuven, 133-170

Yoshimura, S. (Ed.) 2011: エジプト王家の谷・西谷学術調査報告書 [II]: KV A とアメンヘテプ3世王墓(KV22)に隣接する地域, Tōkyō 


\section{ÉTUDES et TRAVAUX XXX / 2017}

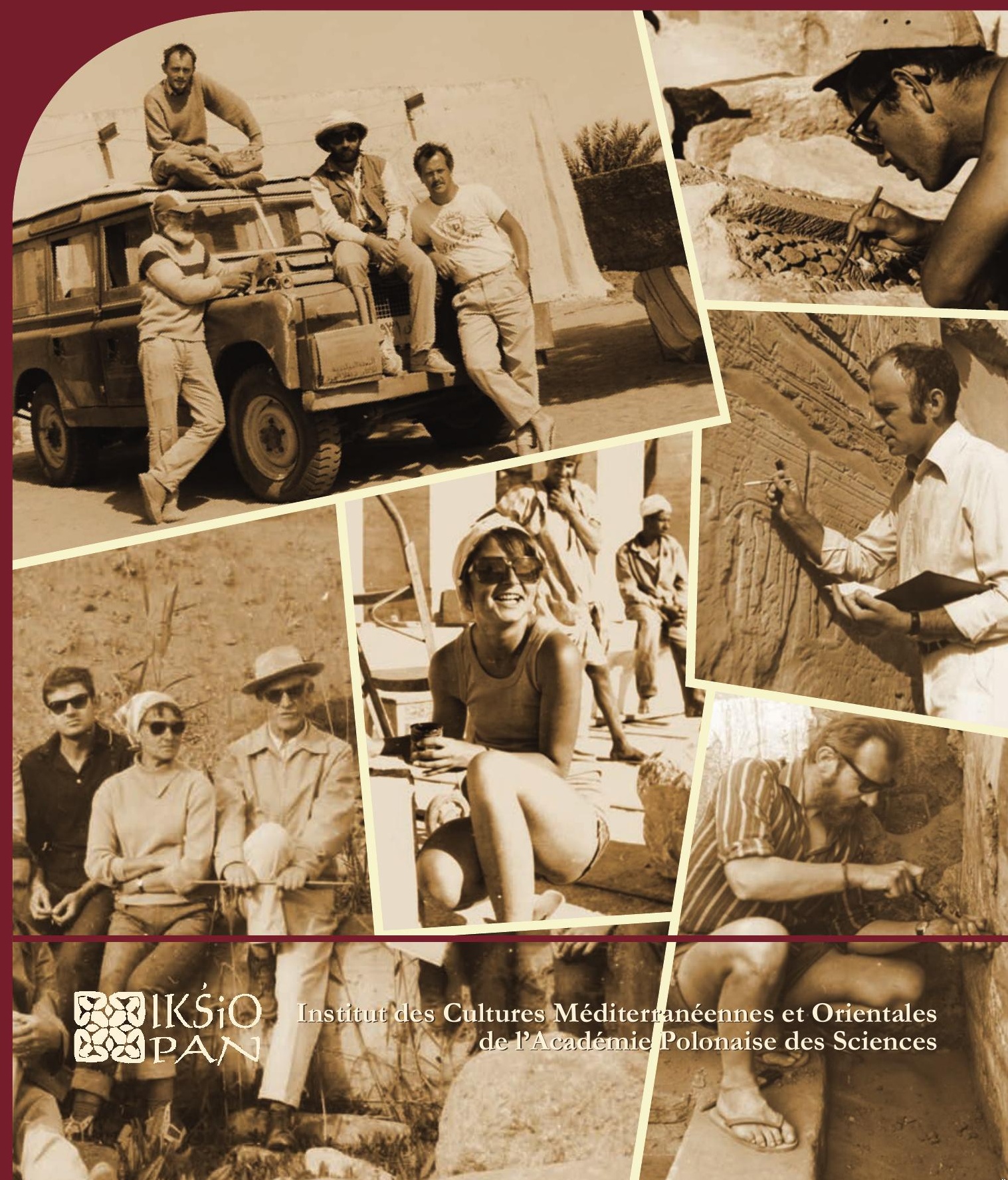




\title{
COMITÉ DE RÉDACTION SCIENTIFIQUE
}

Maciej Makowski - rédacteur en chef

Jadwiga Iwaszczuk - rédacteur et sécretaire de la rédaction

Mariusz Drzewiecki - rédacteur

Maciej G. Witkowski - rédacteur

\section{CONSEIL SCIENTIFIQUE DU JOURNAL}

M. Kobusiewicz (IAE PAS, Warszawa), E. Laskowska-Kusztal (IMOC PAS, Warszawa),

D. Michaelides (University of Cyprus, Nicosia),

J.Ch. Moretti (IRAA-MOM, Université de Lyon 2/CNRS),

D. Raue (Ägyptisches Museum der Universität Leipzig), P. Reynolds (ICREA, Barcelona),

D. Welsby (British Museum, London)

\section{COMITÉ SCIENTIFIQUE DE LECTURE}

J. Holaubek (Institut für Ägyptologie, Wien), S. Ikram (AUC, Cairo),

K. Innemée (Universiteit Leiden), J. McKenzie (Faculty of Oriental Studies, University of Oxford),

N. Strudwick (University of Cambridge), A. Loprieno-Gnirs (Universität Basel),

Ch.E. Loeben (Museen für Kulturgeschichte, Hannover), Y. Tristant (Macquarie University, Sydney),

V.W.J. van Gerven Oei (University of Aberdeen), A. Peignard-Giros (HiSoMA-MOM, Université de Lyon 2/CNRS), J.A. Ostrowski, E. Papuci-Władyka, J. Śliwa (IA JU, Kraków), R. Czerner (WUST, Wrocław), A. Ćwiek (IA AMU, Poznań), M. Wiewióra (IA NCU, Toruń), K. Domżalski

(IAE PAS, Warszawa), K.O. Kuraszkiewicz (DE FOS UW), M. Barwik, P. Bieliński, P. Dyczek, W. Godlewski, D. Ławecka, S. Rzepka, J. Żelazowski, M. Gawlikowski, J. Młynarczyk, A. Niwiński, T. Sarnowski, D. Szeląg, T. Waliszewski (IA UW, Warszawa)

\section{RÉDACTEUR THÉMATIQUE DU VOLUME \\ Barbara Lichocka}

\author{
AIDE RÉDACTION TECHNIQUE \\ Dorota Dobrzyńska, Mariusz Drzewiecki
}

REVUE DES TEXTES ANGLAIS

Jo Harper 
ÉTUDES et TRAVAUX XXX 
INSTYTUT KULTUR ŚRÓDZIEMNOMORSKICH I ORIENTALNYCH POLSKIEJ AKADEMII NAUK

\section{STUDIA i PRACE}

XXX

\section{Ro IKŚSiO \\ ESA PAN}

WARSZAWA

2017 
INSTITUT DES CULTURES MÉDITERRANÉENNES ET ORIENTALES DE L'ACADÉMIE POLONAISE DES SCIENCES

\section{ÉTUDES et TRAVAUX}

XXX

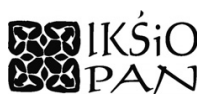

VARSOVIE

2017 
Publication scientifique financée dans le cadre du programme du Ministre de la Science et de l'Éducation Supérieure

« Programme National de Développement de l’Humanistique » pour les années 2016-2021 (projet no 3bH 150099 83)

\title{
HARODOWY PROGRAM ROZWOJU HUMANISTYKI
}

\author{
Copyright (C) \\ Instytut Kultur Śródziemnomorskich i Orientalnych PAN \\ et les Auteurs \\ Warszawa 2017
}

\author{
ISSN 2084-6762 \\ (avant $2011: 0079-3566$ ) \\ e-ISSN 2449-9579 \\ Version première en papier, imprimée en Pologne - 150 copies \\ Version électronique accessible sur \\ http://www.etudesettravaux.iksiopan.pl
}

Édition: Polskie Towarzystwo Historyczne et Wydawnictwo Neriton, Warszawa

Conception générale de couverture : J. Iwaszczuk

Photos de couverture : En haut, à gauche. Vieille Dongola 1991, S. Jakobielski

(debout à gauche), K. Pluskota (debout à droite), B. Żurawski (assis sur le camion)

et P. Wierzbicki (assis sur le camion) (de la collection de B. Żurawski)

En haut, à droite. Palmyre 1964, M. Marciniak au travail (phot. A. Dziewanowski)

Au centre. E. Laskowska-Kusztal au travail (de la collection de E. Laskowska-Kusztal)

En bas, à gauche. Tell Atrib 1962 ; de gauche : T. Biniewski, M. Marciniak, K. Kołodziejczyk,

K. Michałowski, A. Ostrasz, S. Jakobielski et S. Jasiewicz devant eux

(de la collection de IKŚSiO PAN).

En bas, à droite. Vieille Dongola 1976, S. Jakobielski nettoyant le mur (phot. M. Steinborn).

Au centre, à droite, K. Myśliwiec en train des travaux de documentation (de la collection de IKŚiO PAN) 


\section{Table des matières}

BARBARA LICHOCKA

Ergon agathon

Hartwig Altenmüller

$\mathrm{Zu}$ den Feindbildern auf den Zauberstäben des Mittleren Reiches und der Zweiten

Zwischenzeit

Nathalie Beaux

Des $m s w n s w$ de Thoutmosis III à Deir el-Bahari

Briant Bohleke, Nigel Strudwick

A Label for Opening of the Mouth Implements from the Burial of Senneferi (TT99)

and Remarks on the Ritual

Rosa Maria Bonacasa Carra, Nicola Bonacasa

Nuovi dati sugli edifici termali di Sabratha

EDWARD BROVARSKI

A Fragmentary Carrying Chair Scene in Salt Lake City, Utah

Julia Burdajewicz

Wall Painting Decoration from the North-West Church in Hippos-Sussita

of the Decapolis

Mariusz BURDAJEWICZ

From Pagan Temple to Church in Late Antiquity Palestine. A View from

Hippos-Sussita

MAREK ChlodNicki

Early Dynastic Bead Workshops at the Central Kom of Tell el-Farkha.

Patryk ChudziK, Mariusz Caban

Observations on the Architecture of the Tomb of Horhotep in Western Thebes

Krzysztof M. Cialowicz

New Discoveries at Tell el-Farkha and the Beginnings of the Egyptian State.

Amr EL-TiebI

Four Wooden New Kingdom Female Statuettes in the Egyptian Museum, Cairo 


\section{Naguib KanaWATI}

Ritual Marriage Alliances and Consolidation of Power in Middle Egypt during the Middle Kingdom

Adam Łajtar, Jolanta Mlynarczyk

A Faction Acclamation Incised on a Pithos Found Near the North-West Church at Hippos (Sussita)

Adam ŁaJTAR, Grzegorz OchaŁa

Two Private Prayers in Wall Inscriptions in the Faras Cathedral

Adam Łajtar, Anna Poludnikiewicz

Medicinal Vessels from Tell Atrib (Egypt)

JaCeK Michniewicz, Jolanta MlynarczyK

Petrographic Variability of the Fabrics of Wine Jars from Sha'ar-Ha Amakim as a Reflection of Differences in Their Provenance and Chronology

Iwona ModrzewsKa-PianetTI

Les importations d'amphores Dressel 20 en Gaule Cisalpine

Arthur SEgal

Samaria-Sebaste. Portrait of a polis in the Heart of Samaria 409

JOACHIM ŚLIWA

The Motif of a 'Blind Harper' in an Unexpected Place

MONIKA WIĘCH

Searching for the Kitchen in the Early Roman Phase of the 'Hellenistic' House at Nea Paphos (Cyprus)

Abréviations 
THE VOLUME IS PUBLISHED TO CELEBRATE

THE $60^{\text {TH }}$ ANNIVERSARY

OF THE ESTABLISHMENT OF

THE RESEARCH CENTRE FOR MEDITERRANEAN ARCHAEOLOGY POLISH ACADEMY OF SCIENCES

FOUNDED IN 1956

WHOSE MISSION IS CONTINUED BY

THE INSTITUTE OF MEDITERRANEAN AND ORIENTAL CULTURES

OF THE POLISH ACADEMY OF SCIENCES 